\title{
RATIONAL OR COLLABORATIVE MODEL OF URBAN PLANNING IN SERBIA: INSTITUTIONAL LIMITATIONS*
}

\author{
A B S T R A C T
}

This paper outlines the basic characteristics of the rational and collaborative model of urban planning. The situation in which urban planning in Serbia has found itself in has been analyzed. In the circumstances of the undeveloped fundamental institutions of the democratic and market-oriented society, the lack of the necessary rationality and simulation of the basic models of planning is perceived in the planning practice in Serbia. The request to explore aspects of a wider reform agenda of planning practice has been highlighted. The transformation of planning comprises a fundamental reorganization of the institutions, development of the analytical framework, change in the planning approach, i.e. the change of the planning culture. The basic position in the paper is that those changes can be realized only by building and pinpointing the system in which planning is performed, namely by defining the institutions of the socio-economic framework: the market, the private ownership and its protection, as well as the rule of law. 


\section{INTRODUCTION}

For quite some time Serbia has been awaiting the essential changes in the system of planning towards adaptation of the urban planning to the requirements of supporting the democracy, development, sustainability and equality. In practice one comes across a great confusion, resulting from the vague definitions, the role of planning, the presumptions and the framework for action, scope and type of the intervention. In theory, also, there are no professional capacities that would be able to review either the inherited, socalled 'rational' model of planning or the new 'collaborative' model, which is introduced through the process of strategic planning and with the assistance of the international organizations. In socialist period of development, planning relied on the normative theories, whereas the critical, analytical theory was practically non-existent, namely, had no influence upon the practice. In such conditions, it seems that the only likely starting point is the establishment of the elements of the changed socio-economic system, the basic institutions of the system, which would make the rational debates on the necessary selections and transformations of urban planning possible.

Urban planning within the existing incomplete market, socio-economic and legislative framework in Serbia presents a rather challenging (controversial) activity. In the circumstances when the market still does not function to the real extent, when the actors and competent authorities have not been articulated, namely their actions have not been directed towards the rationally defined interests, with decentralization which exists only declaratively, there is an attempt at applying the global experience and methodologies of work.

The selection of the model, the procedure and method of planning is the strategic goal of 'getting planning right', adapting to the contemporary development environment and presumes the critical analyses of the existing models in developed countries. Even though it is assumed that in the formal system of planning in Serbia there is a rational model at work and in the informal one the collaborative model, by comparing the characteristics and requirements of both models it can be stated that actually, neither of them seems to exist, in the ultimate sense of it. Our starting thesis is that in the specific circumstances, namely in the context of non-defined fundamental market institutions, rational decision making within both models is impossible and ultimately leads to the failure of planning.

This paper consists of the four basic parts. The first part, transition and globalization, explains the changed socio-economic context in which urban 
planning in Serbia is operating. The second part analyzes the characteristics and presumptions of the rational model of planning. The third part is devoted to consideration of collaborative method of planning whereas in the fourth part, the necessary prerequisites for the reform of the planning system in Serbia are analyzed.

\section{TRANSITION AND GLOBALIZATION}

The process of transformation of the socio-economic system in post-socialist countries of the East and South-East Europe is a complex process having two parallel courses: on the one part, the direction of adaptation to with the pluralistic market economy is pursued, whereas from the other part, falling into dramatic globalization processes, primarily, the global competition is imposed (Musil, 2005). Unlike other East European countries, the fundamental changes have not been completed in Serbia, changes that are substantial for the advancement of the new democratic, market-oriented system: privatization and restitution, introduction of the market, first of all within the field of the urban construction land, introduction of the real estate taxes, decentralization of decision making and the competences at the local level of governance, as well as the provision of the efficient jurisdiction.

During the past decade in Serbia the discussion was held regarding the future reorganization of the system of governance, decentralization and re-distribution of authority. The traditional, so-called, rational urban planning, inherited from the period of socialist development and slightly adapted in the period after 2000 is not capable of coping with the complexities of the new market-oriented and democratic system. It has proved as completely inefficient, it is criticized from all sides and therefore the replacement with collaborative model of planning is proposed.

The complexity and fragmentation of the contemporary world requires new forms of governance. As stated by the numerous Western scholars and advocates of the collaborative model (Healey, Innes, Friedmann, and Forester), the participation of various relevant actors, their cooperation, exchange of information and harmonization of interests are the key factor, an imperative of contemporary decision making and spatial development management.

The change of the model of planning in the developed capitalism occurs under the influence of the requirements of the practice and is explained in the works of planning scholars in the context of Western developed countries, theoretically 
based on Habermas' theory of communicative action which focuses on the issue of participation, communication and dialogue (Healey 1992; 1997; Healey, Khakee, Motte\&Needham 1997; Sandercock 1998; Fridmann, 1987; 1992; Forester, 1987, Innes, 1995). On the other side, the authors, starting from Foucault, study the relations of the unequal power and the effect that power has upon understanding and defining the various forms of rationality, namely examining the rationality in the context of power (Flyvbjerg, 1998; Hoch, 1996). One can gain an insight there into transformation of the rational model, form the model based on the role of the state and presumption of the possibility of realization of the optimal urban form, towards the model that emphasize the necessity of cooperation of the various key actors as the base of the efficient governance. The processes in different countries lead to various models represented in planning practice and produce the combination of the rational and collaborative governance that acknowledge and respect the relations of power in the society.

A significant change that can be perceived in the contemporary planning is the change from the ethically based decision making (in the public interest) towards decision making based on the dominant economic criteria. The importance of costs and benefits in relation to the concrete actions undertaken is stressed, opposed to the idealized planner's model which is based on the evaluation of the consequences which certain actions have on different social groups, including the consequences upon the future generations. It is interesting to notice the controversy in modern planning between globally proclaimed ideology of sustainable development, the tentative, ethical, complex approach, on one side, and the narrow economic and financial consideration and evaluation in relation to the concrete decisions, on the other side.

In order to be able to analyze and consider the adequacy or adaptation of planning to the contemporary requirements one should have in view the development of the social framework in the four key fields: state, governmental power - executive and legislative; civil society - social power (physical persons, individuals, households, civil associations); corporative economy - economic power, corporations and financial institutions (legal entities); and political community, political power - social movements and political organizations (Friedmann, 1992, 27).

The changes of the planning system certainly do not happen through theory, but through pressures within the practice. In order to connect the changes to the basic characteristics of the market-oriented and democratic system at all, it is first of all necessary to define the basic institutions of that system. 
However, limited to the review and to the analyses of planning in the countries of developed capitalism, planning theory in Serbia addresses transferring of some segments which are comprehensible also within the actual planning system in Serbia, which creates the illusion that certain relations could be established and experience and analytical findings used (such as debates regarding the issues of decentralization, participation and role of planner as mediator among different interests, etc.). There is the logical controversy that should be emphasized. How can a connection be established, a parallel between planning in the developed countries and planning in Serbia when there are no common presumptions, namely fundamental institutions on which the theory in the west (primarily the United States) is based and which the practices deal with... the market, precisely defined private ownership (generally both the private and public ownership) within the field of land and real estate, land pricing mechanism in accordance with the market price, taxes, proper regulations, or legal system, the courts that make resolving of conflicts possible?

Therefore, the conclusion can be derived that in order to be able to discuss the parallels between planning in the developed market-oriented society and planning in Serbia at all, in order to correlate the changes to the basic characteristics of the market and democratic system, it is necessary first of all to define the fundamental institutions of the system and to provide their functioning. As shown by both the practice and theory, that is the basic prerequisite of both the rational (particular as well as general) and also of the collaborative decision making.

We believe that an exhaustive analysis of the existing model of planning, which is presumed to be the rational one, is required in Serbia as well as the familiarization with the basic features of the model being developed in the countries of the developed capitalism (rational collaborative model). The starting thesis, the hypothesis, is that the rational model which was present in Serbia during the time of socialism and has continued to live in practice today, is not a rational one in the true sense of its meaning. Also, the thesis is presented that the collaborative model essentially does not replace the rational one, in the developed world either, but is in fact the addition to it, namely, a more precise articulation of the previous model in conformity with the recognition of the powers influencing planning in the given social and economic conditions.

All requirements that are set presently and which are based on the nature of contemporary capitalist society, developed global market and democracy (Healey, 1992; 1997; Innes, 1995; Innes \& Booher, 1999) comprise the fundamental institutions and basic actors within the private, public and civil 
sectors being developed against the emphasis of the governance role. The condition for the change of the system is also the competence of the actors to perform the roles they have been assigned. The differences between the state, power, society and the public sector in Serbia have been perceived but have not been defined in a corresponding manner in the sense of operationalization in relation to the concrete issues and tasks being of particular significance for planning. The development of the democratic society necessarily imposes involvement of the relevant stakeholders into decision making. There are two possible forms of inclusion: by simulation within the rational model (identification of all groups which the proposed intervention could affect and the analysis of their interests and influences, as well as evaluation of the support or opposition to the proposed interventions) and, secondly by direct participation within the collaborative model.

\section{RATIONAL MODEL OF PLANNING}

The comprehensive rational urban planning has for long time been the dominant model of spatial development governance. Urban planning has developed from the engineering technical approach to spatial development to be transformed in time into social governance (Friedmann, 1987; 1996). The rational model of planning is tightly connected with the idea of state intervention in the right to develop. The generic model of the contemporary rational planning introduced in capitalist democracies presumes the possibility of the long-term management of the process of spatial development and the determined forms of professional action that are appropriate in different situations, for all times and all places. In its basic form the model is associated with the conviction that spatial development can be controlled by introducing scientific techniques and adequate technologies and it comprises the centralized process of "topdown" decision making, without the participation of the public. The general model which is also used nowadays presents a precisely developed instruction for professional expert problem solving within the public sphere. As such it becomes institutionalized into bureaucratic governing structures.

The model stresses the planning's role in correcting market failures regarding externalities, and points out essential tasks which are necessary for the practice of spatial development management and control. It is based on the instrumental rationality, namely, on the expert's analysis which enables setting of goals, identification of alternative courses of action, evaluation of the means by which the goals would be achieved and the creation of systems for implementation. These rational planning key elements can iteratively be worked out in the process to a greater or lesser extent depending on the specific situation (Larsen, 2003). 
Rational planning includes the knowledge and the concepts from various disciplines, primarily coming from economic and political sciences (Meyerson, \& Banfield, 1955; Banfield, 1961). Justifications for planned intervention are found in preservation of resources, reduction of undesired development and construction effects, rationalization of the public expenditures and promotion of the quality of the environment. Planning makes use of the techniques of analysis, primarily the quantitative analysis, the analysis of the costs and benefits, modeling, and determines the criteria and indicators (Klosterman, 1985; Bertaud, 2004). The development of technology and computer modeling (design) affects the rational planning to a significant extent since it makes possible manipulation with a great number of relevant spatial data, as well as conceiving the models simulating the patterns of urban development and also the evaluation of the effects of certain choices made between the alternatives (Klosterman, 1994; Batty, 1995).

The selection of information on which planned decisions are based is linked to the concrete political practice within which problems, their interpretations, motivations of the key actors, limitations and risk are defined (Friedmann, 1987). Even though it is based on the information on various groups of actors, namely stakeholders, the results of the process are only intended for the decision makers, the competent government authorities. The critics of this model point to the assumption of the ideal situation inside which the conditions for the functioning of the model are created, the difficulties in implementation of the plans and policies, as well as to the various deformations which are caused during this process under the influence of politics and different influential groups (Fainstein \& Fainstein, 1996; Shmueli, Kaufman, \& Ozawa, 2008).

The starting point on which this model is based is that the planners can collect and analyze all necessary data, that they possess experience on the basis of which they can define the public interest, determine optimal proposals in conformity with the tasks set (by democratically elected government for which it is presumed to represent the public interest), verify them by means of the adequate criteria, especially economic ones, and thus select the best solutions in all fields. In market conditions the model focus, primarily on the three areas of actions: defining land use regulation, primary infrastructure investments and manipulations of the real estate taxation system. It is supposed that proposals within these fields are inter-consistent and in harmony with the government strategies (Bertraud, 2004).

The process of planning comprises six basic stages which include defining goals and priorities, formulation of strategy, collection and analysis of information, 
defining and evaluation of alternatives, monitoring and evaluation of realization in respect to the goals. The process is not linear but an iterative one, involves numerous repetitions and verifications in conformity with the new requirements or findings. This model has been modified during its development under the influence of specific circumstances or requirements for adaptation to the contemporary governance practice (Webster, 1994). The basic issue which the debates revolve around is whether the process starts with defining the goals or by determining the problem. In the second alternative the process phases are: identification of problems, evaluation of stakeholders, namely, relevant actors (stakeholders) and their available resources formulating alternative strategies and selection of the most favorable one, implementation, monitoring and evaluation of the results.

Rational planning in increasingly more sophisticated and more complex world has lesser possibilities of anticipation, simulations of interest and behavior of different actors. That is the reason why the scope of rationally conceived plansand policies becomes smaller, changes from the comprehensive orientation to the selective one, is limited prevailingly to the development of infrastructure, larger areas of urban reconstruction namely selection of regulatory rules and special policies. At the same time the concept of consolidating public interest which can be defined professionally is challenged. For the purpose of achieving better insights into the interests, motivations, positions of the different relevant groups that as a goal has as efficient implementation of plans as possible, planning process is modified and participation becomes an integral part of the process. In the practice different positions in the process and forms of participations are introduced, from the public insights upon the completion of the professional work as well as various forms of consultancies and involvement of the plan implementation key actors in the selection and evaluation of the plan alternatives (Klosterman, 1985).

The process is mainly in the hands of professional planners, the experts who find the responses to the requirements formulated in the political process. The planners are required to have the insight into political reality of the concrete context, as well as the rational, scientific and formal-practical knowledge. Great skills are required to provide even minimal intervention in the complex conditions of space production in modern cities. However, understanding and setting up the framework within which the market will work presents the basic condition for successful rational planning (Pasour, 1983). It is necessary to monitor and research market trends in detail. Understanding the changes at the market is the condition, but certainly does not guarantee the success in plan implementation. Yet, that is not the only criterion. How important it would be 
depends on the local government policies, namely on the instruments at its disposal for their implementation.

A great amount of data and complex analyzes connect the traditionally rational planning model to the governance models. Even though that is not the case in practice, in the ideal model it is possible to imagine a technocratic planning, fully informed, qualified (competent) for complex objective analyzes and evaluations of alternative choices of action which make the basis for political decision making. Understanding the city and planning, which is more complex than ever, requires continuous advancement of traditional models which has been attempted through the theory of chaos and elaboration of the key concepts of complexity, comprehensive simulation of city functioning and forecasting its future (Batty, 2008). Also, the initial concept of comprehensiveness in the conditions of rapid changes is mainly abandoned and planning is orientated only towards the chosen, key aspects of the urban environment and monitoring the process of change which present the basis for decision making on the desired actions. Various forms of support which information technologies may render to planning are under consideration, (Batty, 1995; Maruna, 2008), as well as the review of adequate governance models (Webster, 1994).

Rational model of planning is primarily based on the principles for which on one part it is considered to have systematized core areas of knowledge, whereas, on the other part it is criticized as being a narrow scientific rationality. These principles are linked to the public interest represented by planning. The basic requirement placed within the rational context is realization of compromise. In order to achieve the compromise, it is necessary to replace the conflict of principles with the conflict of interest, namely define different interests and their stakeholders. That involves an adequate knowledge. How to acquire it in the dynamic and uncertain environment? Contemporary theory of planning as well as the experience of the practice recommends upgrading the knowledge by using best practices (good examples). That certainly is a valuable source of information but a question of comparing the situations, solutions, instruments in rather versatile environments is raised.

Rational model of planning incorporates several basic presumptions. The local government, the political apparatus, has clear visions of development and can formulate the goals, objectives and priorities. Authorities also have great power within the field of decision making, first of all they have the right to regulate the use of land and grant construction permits. Further on, the essential prerequisite is also a powerful financial position of the local, city authorities 
which through collection of local taxes, namely, on the basis of their own property (the dominant land owner) or by means of transfers from the central level, may make the implementation of the planned interventions possible without negotiating with the local stakeholders. Thereby it is understood that the governing authorities when defining the vision of development are in the position to neglect particular interests of the individual powerful groups (Lind, 2002). It is interesting to mention that it was often considered that such ideal environment existed in socialist society. Certainly the rationality of planning in socialism can be debated and denied, first of all from the standpoint of nonexistent real prices, land prices and their changes primarily, and irrational proposals in that sense (Betraud \& Renaud, 1997). The problem is that in post-socialist societies such form of local development governance retains a specific culture of planning which consequently means disregard of the changed conditions, market criteria and real power of the actors at the market.

Even despite numerous disadvantages and criticisms, primarily directed towards impossibility of defining the public interest, unreal expectations that the politicians, government authorities, may agree on the goals of planning at the beginning of the process, which makes the assumption of the model (Lindblom, 1959), of the problematic relation between science and politics, namely irrelevance of the scientific analysis for political decision making, and the impossibility of analysis of a great number of developing alternatives - the rational model of planning in different forms still presents the model of planning which has been represented the most in practice. The model is transparent, connected to the fundamentals of the urban planning profession, rooted in bureaucratic procedures of decision-making; it results from the essence of the modern awareness on the possibility of establishing order in the society and space.

All criticisms of the rational model have found their place in the alternative collaborative model which functions nowadays as the expansion and supplement of the basic rational model.

\section{COLLABORATIVE MODEL OF PLANNING}

There are numerous reasons (globalization, new market conditions, dynamic economy and social changes) that affect the transformation of the urban planning of the past decades towards planning which is to a greater extent market orientated. Collaborative method of planning is the response, the adapted framework of the new form of planning within the public sphere. Neo- 
liberal ideology imposes creation and harmonization of the social institutions that suit its purpose, the institutions which enable and assist the free flow of investments and construction. In that respect a parallel between the collaborative planning and the invisible hand of the market can be established. If the invisible hand in economy is the market, then in this model of planning it is the collaborative process (Robertson \& Choi, 2009).

The starting point of the collaborative planning is the requirement of efficiency, namely, the necessity of implementation of planned policies. To that end, many scholars believe that the role of planning is above all to make the market operation possible. Lindblom, the supporter of the gradual adaptation approach appropriate in the conditions of uncertainty and limited rationality (incremental planning), emphasizes that market is a system of social coordination, a big coordinator the role of which extends exclusively over the economic sphere. The market provides the measure of price efficiency which makes greater degree of efficient choices possible (Lindblom, 2001). It is democratic given that the basic information on prices is available to everyone. However, the market shows also the inefficiencies and waste and therefore it is the task of the government to regulate the market. That is the crucial tasks of the government because if the government does not play well its regulatory role the market will not work at all. Also, through intervention, planning, the government promotes certain freedoms which are not secured by the market.

Given that in the contemporary dynamic society the representation and simulation of all interests and relying on the defined principles as well as decision making within strictly defined rules presents a problem (rational model), the advantage is granted to collaborative governance which by its nature is self-regulative. Such governance and planning, contrary to the traditional one founded on the established administrative routines, makes the innovations and adapting to the new context possible (Healey, 2004). Also, the supporters of collaborative planning believe that cooperation and communication among different interests in the process of decision making presents the promotion of the democratic process (Forester, 1989; Friedmann, 1992; Healey 1996; 1998; 2003; Hoch, 1996, Innes, 1996; Innes \& Booher, 2004).

Right at the beginning it should be clarified what is understood as collaborative model of planning. There are numerous definitions which can mainly be reduced to the situation of governance in which the public institutions directly involve the groups of different stakeholders, primarily the private ones, but also from the public and non profit sectors in the process of collaborative decision 
making. The process is formally regulated but also flexible, orientated towards overcoming the conflicts and consensus achievement, with the ambition of reaching an agreement in respect of implementation of the public policies (plans, projects, programs).

Recognizing and respecting multitude of different interest and different rationalities behind it (which it is difficult to cope with at the professional level), is understood as inclusion of actors in the decision making. Urban planning, being the public policy in the situation of rather dynamic market, finds itself in between the responsibility towards the citizens (through expert's rationality) and cooperation with them, working out compromises and adjustments, as partners. The exchange of information and forming of coalitions, as well as negotiation are placed in the center of the process.

The stakeholders, groups of investors, business organizations, the elected representatives of the government, non-government organizations, and associations of the citizens have direct or indirect stake in the project. As they can affect or be affected by the actions, objectives, and policies, they bring their knowledge, interests and expert opinion into the process as well as innovative solutions. The selection of the participants and the level of participation depend on the type of problems under consideration (Brody, Godschalk \& Burby, 2003; Weber, \& Khademiain, 2008). To that end collaborative planning integrates two approaches to planning: the professional one (the rational one) and the political approach of gradual achievement of compromise (the limited rationality), namely, present a process of mediation and aggregation of preferences (agreement between the actors). Involvement of stakeholders is necessary in the different stages of the process: formulation of the vision, selection of goals, priorities and alternatives as well as the plan implementation, not only in the stage of the public review upon the plan completion. That active participation and reaching of agreements by different actors provides legitimacy to the decisions which are passed by and its importance was recognized even in the planning practice in post socialist countries (Lazarević Bajec, 1996).

The model assumes a regulated market and rational actors which are well informed, and have clearly defined interests (Lind, 2002). Analyzing actual processes of adaptation of planning under the influence of globalization, Bengs emphasizes the significance of deregulation at the real estate market. Reducing the limitations for free investment, and furthermore, decentralization of decision making, being the essential factors of reorganization of the system 
of spatial planning and change of the role of the public sector from intervention and control towards encouraging and promoting development (Bengs, 2005). In order to avoid numerous conflicts which cannot be resolved with ease planning relinquishes a part of its traditional competences to the market and narrows down the scope of its activities to the issues that local administration have the power and resources to influence.

In collaborative governance it is first and foremost important to clarify the basic issues. Who does the system respond to? (Bryson, Cunningham, \& Lokkesmoe, 2002). Whether the participants in collaborative governance may pass the joint decisions which would reconcile the interests of certain groups with the common, social interests? While observed in general, as per definition, the system of planning being the system of public policies should in general accommodate everyone and all, the public, whereas in collaborative model the public interest is replaced with the aggregate of certain group stakeholders. It can be discussed whether the system conceived on harmonization of the individual interests in the ultimate outcome leads to better results and generally greater social efficiency and responsibility. To that end, it has been stated, that even when certain groups represent only their narrow interests, a wider, social responsibility could be achieved through their cooperation (Roberson \& Choi, 2009). On one part collaborative governance involves participation of a greater number of interested actors, more clear commitment (dedication), more efficient conflict resolution, confidence building among the participants and the balance among different interests. (Innes, 1995; Healey, 2004; Booher, 2004). On the other part it can be supposed that when representing particular, group interests, it is to the cost of the general social interest (Bengs, 2005), particularly in the situations when the representatives of wider interests have not been adequately qualified, informed or competent (as is the case in the developing countries, especially in the conditions of great social transformations, e.g. transition, when the fundamental institutions of the new system have not been established yet).

The key issue in collaborative model is the problem of interest, information and social effects. As Bengs emphasizes, in neo-liberal context it is easier to operate with interests than with principles. Principles are long lasting, and the interests are variable, and adapt to the circumstances. Consequently, in collaborative model concept of "citizens", "actors" is replaced with the concept of "stakeholders" (the interested subjects, holders of \{material\} interests). It is thereby suggested that greater importance is assigned to particular, group interests than to the collective, public interest (Bengs, 
2005). The central problem of collaborative planning is the concept of the public interest. Bengs believes that denying the existence of the public interest in collaborative model, as something that cannot be formulated within the context of representative democracy, means neglecting the facts that in the contemporary world there are numerous issues around which public interest has clearly been formulated, both at the international level (through various charters), and also at the national level (acceptance of these charters through laws and regulatory rules). In the first place it concerns the issues such as protection of environment, heritage, culture, etc. According to Bengs these are not the interests that everyone individually would support, but they certainly concern the collective interests. These are the interests that are supported by democratically elected authorities, and thus their legitimacy cannot be denied (Bengs, 2005).

In the literature on collaborative governance theory we come across different opinions on whether the public interest can be interpreted as the sum of the individual interests or it presents something greater than that. Also, a question is raised who the public interest is formulated by? Can that be expected from the elected representatives of the citizens, democratic institutions of government or from the especially responsible, in that respect qualified, competent experts, the planners? It seems that the models of planning cannot be considered without some type of responsibility towards representing the public interest. In that respect, the responsibility of the experts, planners in public service within different models comprises efficiency, effectiveness but also the responsibility in respect to all citizens.

The major focus in collaborative model is on implementation of agreed plans, policies and programs. In order to implement the decisions it is necessary to recognize the difference in the interests and their possible connections (Shmueli, et al., 2008). In respect to the differences among the certain groups, particular interests are more important than the general, public interest. First and foremost the investors are in the focus of attention. They would be building on the local territory only if it was made possible that their share in the profit be greater than their share in the costs. For example, in the radically reduced model of planning just to negotiations, if a certain property owner wishes to alter the use of building or land, the negotiations are reduced to reaching an agreement between the interested parties, namely, striking deals with other property owners in the vicinity, upon which the proposed change could have an impact. As the services in this case of ideal market are also privately provided, the issue relates only to the agreement on the price of providing the connections. 
In that case the role of the state, and thereby the planning as well is actually reduced only to defining and protection of rights resulting from private ownership, namely enabling the process of agreement reaching and protection of interests through efficient judicial system (Lind, 2002). It can be concluded that it makes a minimal, however also the basic role of the state in market economy. Without defining and regulation of the rights and obligations based on the private ownership planning within the marketoriented society cannot be discussed.

On the other part, even though contradictory, it is believed that the model has the important role in promoting democracy. In the ideal situation, establishing the transparent process of decision making is requested, the process that incorporates all interests, those which are represented in the process and those that are not and, basing the process on the accurate information which everyone has the right to review (role of the planner, the experts) (Healey, 1997; Amdam, 2002). To that end, collaborative model represents the continuation and enrichment of the rational model in which the planners as the representatives of the social goals (the public interest) and coordinators of information have an important role in achievement of successful negotiations (Schmueli, et al. 2008). An important issue could be raised: whether in the collaborative planning model the decision making of the democratically elected representatives is replaced with the striking deals with the "stakeholders', the agents of material interests? Everyone can participate in the process; however, the powerful and organized ones dominate the process (Innes, \& Booher, 2004, 421). In search of the answer it would be necessary to take into consideration also the replacement of the concept of government with the concept of governance which is explained by expansion, and not shrinking of democracy.

As the emphasis is translated from the product to the process of planning, namely, deciding on the spatial development and spatial policies, thus the form and character of decision making is placed in the focus of attention. "Topdown" decision making is advocated, as more appropriate, efficient (first of all in respect to implementation) in relation to "bottom-up" decision making. Although "bottom-up" need not, as noticed by many authors (Amdam, 2007) necessarily be understood as greater democracy in decision making. Decentralized decision making, bottom-up, may, first of all, mean decision making based on coalition of the particular (local) interests, both private and public ones, namely, the interest of individual groups (mostly the powerful ones, those in possession of resources and interest to build) which are able to define their requirements and to harmonize them among themselves. Thereby, 
each group representing particular interests has the responsibility in the process of decision making, first of all towards the interest of the group they belong to. In that respect it could be presumed that it concerns exclusively the agreement of the groups holding power, whereby those groups of actors without power or those that have not adequate representatives are underprivileged. However, the opposite standpoint can also be considered. Through the process of negotiation, harmonization of interests and overcoming of conflicts, particular groups, by realizing necessary wide coalitions, in a certain manner attain also the collective social interests and goals.

Many authors believe that collaborative process is suitable to the societies having stable institutions and that it does not lead to the essential structural changes but only to the decisions which can be applied in the existing, or through collaborative process adapted and innovated framework. (Scmueli, 2008).

In collaborative model the starting point is the fact that versatile information required for planning and decision making in complex conditions can hardly be provided at one place by the experts in the public service. Information and knowledge required to understand and resolve complex problems are in the possession of the different participants in the process of planning and decision making (Connick \& Innes 2003; Booher \& Innes, 2002). The stakeholders provide their information and expert opinions themselves on the basis of their special requirements. The process of participation and collaboration is at the same time also the process of exchange and completing the information. To that end it is estimated that collaborative planning has significant advantages in relation to the rational one, providing that it is possible to achieve ideal conditions for participation, namely, organized space, arena for communication and cooperation.

If the information obtained in the process is to present the basis for efficient decision making, it is assumed that the participants are familiar with the elements of the system in which they operate (the informed participants) and, that there are defined fundamental institutions of the system which are recognized by all, both the professional and non-professional participants. Certainly the issue of the lack of information which could eliminate uncertainties in respect of shortterm and long-term consequences of the decisions is still perceived.

Even though the choice between the rational and collaborative model is frequently discussed, in practice it most often concerns the synthesis of the two 
two models. Radical interpretation of collaborative model emphasize the role of would lead to the diminishing of the role of experts directing their tasks towards mediation and facilitation. Planners are just participants, equal with the others. Stakeholders, civic leaders, not planners, had to be at the core of planning if plans were to be implemented. That obviously is not the case. The planners possess particular expertise, including formal training, qualifications regarding analysis, synthesis of different aspects as well as greater responsibility, not only for process development (the skill in the sense of mediation and assistance) but also for finding professional solutions on the basis of which this cooperation is carried out. Responsibility is understood as strengthening of rationality and professional inputs in the process of joint work. Therefore it seems unjustified to talk about two different, separated models, planning approaches, but more about the combination the two. The presumption for both is the transparent participation and responsibility of the experts, namely all parts of public administration.

Rationality in decision making also exists in both the one and the other model. Collaborative model is at the same time rational given that within the process information is used in order to identify the requirements and to shape the alternatives among which the selection is made. The stages included by the rational model, such as data collection, analyses, defining of alternatives and their evaluations make also the part of collaborative process. The difference being that in collaborative process the stakeholders directly participate in the process within or outside strictly determined procedures, directly bringing their information in and establishing independent relationships and coalitions, on the basis of the real and simulated interests. Harmonization of their relationships, with or without the participation of experts, the planners, places the process of negotiation in the focus and through which conformation of interests and overcoming of conflicts is achieved. The assumption is that the public sector, through the experts, actively participates in different stages of planning, from provision of the special, detailed information, to coordination of negotiation, analysis and evaluation of the consequences of the planned decisions. Even though it seems that the work of the planner has been facilitated, by transferring a part of responsibilities to other participants, the fact is that has become more complex requiring continuous upgrading of knowledge and expert advice. Incompetence of planner to follow particular interests of both the powerful and underprivileged groups in a qualitative manner and to achieve compromises in accordance with the social goals has an impact on the loss of legitimacy of planning. 
THE REFORM OF THE URBAN PLANNING SYSTEM IN SERBIA: SELECTING THE MODEL

Urban planning in the existing incomplete market-oriented, socio-economic and legislative framework in Serbia represents a rather challenging (controversial) activity. Under the conditions when the market does not function fully, when the actors and competences have not been articulated, distinct actions have not been orientated towards rational (market) parameters to a sufficient degree, with decentralization existing only declaratively; there is an attempt at applying the global experience and methodologies of work. Transformation of the field of governance by development from the non-market to the market one is a rather complex process which is time consuming and requires formulation of numerous institutions, mechanisms and instruments.

The introduction of contemporary rational or collaborative planning and its functioning is conditioned by regulation of the basic elements of the marketoriented and democratic society:

- Key market institution

- Resolved land ownership relations (Mijatović, Begović, \& Paunović, 2007)

- Adequate taxation policy (Begović, 2005)

- Forms of planning documents reflecting the essential requirements and, not the formal system of plans

- Defined transparent procedures

- Level of information and competent actors

- Legal sanctions policy

In planning in Serbia there is a combination of different elements of the previous system present as well as the new concepts, methods and practices. On one side, firmly defined, formal (binding) urban planning has been institutionalized. As decision making within this model is not based on the rational decision making which takes into consideration, first of all, the economic parameters, therefore this model of planning could be labeled a simulation of rational planning. On the other part, collaborative model is introduced analogously through informal strategic planning, whereby the emphasis has been placed on promotion of the democracy of the process and education of the actors with an idea that it would lead to transformation of the system as a whole. In this case it also concerns the simulation of the process of cooperation given that the participants do not decide on the basis of the knowledge about real interests, resources and risks. 
The merit for introduction of debate on the change of the planning model in Serbia can be attributed to the international agencies and donors from the developed world as well as to a very small number of the local experts engaged in research in the field of urban planning and governance. The practice of strategic planning at the local level in Serbia which promoted the collaborative model in the past decade presented an extensive activity engaging many participants and large funds. However, more extensive research and evaluation of the effects of the process and planning products within this model has not been undertaken yet (Lazarević Bajec, 2006; 2007; 2009; Čolić, 2009). A small number of studies addressing only some aspects of planning, most often the sociological ones, in search of the responses to the questions opened by transformation of the urban planning in Serbia and the imperative of deciding the sociological ones, in search of the responses to the questions opened by on the new socio and economic system, offer more of ideological standpoints rather than rational, critical analysis (the research finding of S. Vujović, 2004, can serve to illustrate the confusions of different actors).

The incompleteness of the functional market economy and public sector governance in market conditions as a prerequisite for implementation of market relevant policies at the local level present the basic problem faced by the planners. The problem perceived by many planners of post-socialist societies is the lack of the functional market economy as well as public sector governance in the new conditions (Tzenkova, 2007). Serbia falls behind in relation to other post-communist countries (Allock, 200). Land policy has not been laid on the new market bases. Only the work in the field of taxes at the local level which present the basic source of municipality income has been initiated (Begović, 2005). In general, the system framework significant for implementation of the policies has not been completed even though the progress within this sector is of crucial importance for the development of the effective planning and regulation of space related transactions.

In the transition process it is first the economic power that is adapted whereas other areas fall behind. Thereby it is important to perceive the differences between those economic power holders which find the non-defined environment suitable for the purpose of increasing their power and those wishing to protect and promote their activity and the property they possess. The state formally holds the power both at the national and at the local level, enacts the laws, but they are either not adequately enforced, or are not responsive to the actual requirements. Government do not present a motivating framework for the development and neither is in the position to protect the legitimate interests of 
the social groups (Foreign Investors Council in Serbia, 2009): foreign investors have been making the same requirements for years (2002-2009), not to mention the other, less articulated actors, who as regards their problems have to seek the arbitration of the Court in Strasbourg. (Mučibabić, 2009). Civil society is confused, has not recognized the important issues, and is not organized except as regards rather selectively chosen themes financed by the foreign donors. Political communities are limited to numerous political parties of blurred ideologies and concrete objectives.

Given that in Serbia the local governments still hold a strong legal position in determining the land usage, in the new concept of planning it is clear that the decisions will be made in cooperation through more or less successful negotiation between the investors and local governments. In view of that the investors are doubtless the party having more clear and rationally defined criteria than the local community (which does not have the adequate means nor the experts who could analyze rationally all aspects of development initiatives nor represent the interests of the local community, namely different stakeholders) it ensues that despite the legal empowerments (which are granted in principle, but are not made operational into adequate instruments: the existing plans certainly have not been), the public sector, as well as the civic sector are not the equal partners in negotiations. Thus it can be concluded that in the case of Serbia there are no prerequisites for development of either the rational or the collaborative models of development governance, namely at the same time the democratic (protection of rights and interests of different interested subjects, material stakeholders) and efficient planning.

In Serbia after the year 2000 the democratic market-oriented system was introduced declaratively. The market forces operate, however, without any control and unregulated. The interests of one or few actors are satisfied but their agreed actions do not go in the direction of attaining the social goals. Non-existence or inefficiency of the defined institutions on which the regulated system is founded results in mass corruptive behavior, the one of exclusively satisfying the partial interests and policies and deformed spatial development.

The illustrative evaluation of the level of development of the institutions in Serbia by the World Economic Forum in the best way points out to the key problem Serbia is encountering. The success of one country to compete economic-wise with other countries has for years been followed up through regular analyses of the World Economic Forum in Davos (WEF). Each year about 130 countries, which cover over $95 \%$ of the world GDP and international 
trade, are ranked according to the global competitiveness index (GIC). That index expresses the degree of development of 12 key pillars (components) of competitiveness. And, each individual pillar is measured by a number of quantitative and qualitative indicators.

In 2009 Serbia was ranked only at the $93^{\text {rd }}$ place according to GIC and dropped down by eight places in relation to the previous year. It is characteristic that Serbia has been holding such poor placement for several years. The most important fact for our analysis is that the main reason for such low competitiveness is a rather poor condition from the standpoint of development of the institutions presenting the first pillar of competitiveness.

According to the degree of development of the institutions, this year Serbia took only the $110^{\text {th }}$ place out of 133 countries. Given that the degree of development of institutions is measured by 19 indicators, it is symptomatic that according to any one of them Serbia does not climb above the $50^{\text {th }}$ place, and that in ten cases Serbia finds itself above the $110^{\text {th }}$ place. For example, according to the degree of development of the ownership rights it takes the $111^{\text {th }}$ place, according to the substantive judiciary it takes the $110^{\text {th }}$ place, according to favoritism at decision making by the state officials it takes the $112^{\text {th }}$ place, according to the state regulatory rules burden it takes the $129^{\text {th }}$ place, according to judiciary efficiency in resolution of disputes it takes as low as the $124^{\text {th }}$ place, according to the legislature efficiency it takes the $115^{\text {th }}$ place, etc, etc. It is obvious that until there comes to drastic improvement in functioning and efficiency of the key institutions, Serbia cannot improve its international competitiveness seriously. To that end, it is clear that with planning, whether it concerns the rational or collaborative model or their combination, they could not be implemented successfully since it directly depends on the developed and efficient institutional framework which is still non-existent in Serbia (World Economic Forum, 2009).

Great differences in development of the basic institutions between Serbia and the developed countries present an obstacle in understanding the framework and presumptions on which the actual planning is based in the developed countries as well as the dynamic factors which influence its continual adaptation. With the deficient financial and organizational capacities in the institutions competent for the change or adaptation of the system and process of planning there is no adequate base for reorganization of planning in Serbia. Therefore, defining and efficient functioning of the basics institutions of the contemporary marketoriented society and its understanding by all actors involved in the planning 
process is perceived as the first, necessary step in establishing the basis for consideration, criticism and proposing of the new solutions.

That step is within the competence of the state. When the 'installation' of the new system occurs and becomes functional in full the argument supported debate will be made possible as well as efficient inclusion of the experts in building the new system. To which extent it will be rational and to which extent collaborative, is the issue of evaluation and decision of all relevant actors in decision making, as well as their power.

\section{CONCLUSION}

This paper points out the key problems of the planning practice in Serbia. The changes in planning can only be achieved by building and defining the system in which planning is performed, namely by introduction and functioning of the basic institutions of the regulated marked-oriented economy harmonized with the international standards and E.U. norms. On the basis of defined institutions the specific aspects of the decision making, forms and types of planned intervention can be analyzed and critical evaluation made. Thereby, it does not concern the abstract theorizing, but studying the practical issues in connection with the change of environment, political limitations and economic realities. The consideration of rather practical aspect of planning is necessary and which may help in conception of the adequate responses to the issues raised in practice. The focus is on the issues of governance related to the spatial and institutional aspects of the concrete planning environment.

Consideration of some essential characteristics of the rational and collaborative model of planning was not aimed at assessment of the suitability and recommendation for the actual situation in Serbia. The focus was on determining the characteristics and presumptions for functioning of the model.

We believe that Serbia requires an exhaustive analysis of the existing formal model of planning, which is supposed to be a rational one, as well as the comparison with the model introduced into the practice of the developed countries (rational collaborative model). The analysis shows that the 'rational' model which was present in Serbia during socialism and as per many aspects has continued to live in practice even today is not a rational one in the true sense of its meaning. Also, according to research findings the 'collaborative model' essentially does not replace the rational one, and neither it does in the developed world, but presents the expansion and more precise articulation of 
the previous model in accordance with recognition of the powers influencing planning in the given social and economic conditions.

To which extent the one or the other model, namely their combination, presents a better framework for integration into the globalization processes and implementation of grater democracy in the society remains an open issue. The paper has emphasized and provided a rationale for the theses that regardless which direction of what model the adaptation and reform system and process of planning in Serbia would go into, the breakthroughs cannot be implemented without developing the basic market institutions, the real estate market, adequate taxation policy within the field of real estate, protection of private property and contracts and efficient judiciary. Experience from County Level in Norway. Paper to AESOP Congress in Volos, Greece.

Amdam, J. (2007) The emerging Norwegian municipal structure: Alternative options - and their consequences - for the political and organisational reform of the local and regional levels. European Journal of Spatial Development (August) 1-25 [Electronic version] From: http:// tilsett.hivolda.no/ja/Notat/debate_Amdam070830.pdf

Banfield, E.C. (1961). Urban Government: A Reader in Politics and Administration. New York: The Free Press of Glencoe.

Batty, M. (1995). Planning Support Systems and the new logic of computation. Regional Development Dialogue, 16, (1), 1-17.

Batty, M. (2008). Cities as Complex Systems: Scaling, Interactions, Networks, Dynamics and Urban Morphologies. Working paper. CASA Working Papers (131). London: Centre for Advanced Spatial Analysis (UCL).

Begović, B. (2005). Porezi na imovinu u Srbiji: postojeće stanje i predlog reforme . Finansije,1-6, 37-58. 
Bengs, C. (2005). Planning Theory for the Naive? European Journal of Spatial Development, 18, 1-10. [Electronic version].From: http://www.nordregio.se/EJSD/debate050718.pdf

Bertaud, A. \& Renaud, B.(1997). Socialist Cities Without Land Markets. Journal of Urban Economics, 41(1), 137-151.

Bertaud, A. (2004). The Spatial Organization of Cities: Deliberate Outcome or Unforeseen Consequence? World Development Report 2003: Sustainable Development in a Dynamic World. Washington: World Bank.

Booher, D. E. (2004). Collaborative governance practices and democracy. National Civic Review,93(4), 32-46.

Booher, D. E., \& Innes, J. E. (2002). Network Power in Collaborative Planning. Journal of Planning Education and Research, 21(3), 221-236.

Brody, S. D., Godschalk, D. R., \& Burby, R. J. (2003). Mandating Citizen Participation in Plan Making: Six Strategic Planning Choices. Journal of the American Planning Association, 69 (3), 245-265.

Bryson, J. M., Cunningham, G. L., \& Lokkesmoe, K. J. (2002). What to Do When Stakeholders Matter: The Case of Problem Formulation for the African American Men Project of Hennepin County, Minnesota. Public Administration Review, 62(5), 568-584.

Connick, S. \& Innes, J. (2003) Outcomes of Collaborative Water Policy Making: Applying Complexity Thinking to Evaluation. Journal of Environmental Planning and Management, 46(2), 177-197.

Čolić,R. (2009) Participacija u strateškom planiranju gradova i razvoj saznanja - primer Strateškog plana razvoja Niša. Unpublished doctoral dissertation. Belgrade: Faculty of Architecture.

Fainstein, S..\& Fainstein, N. (1996). City Planning and Political Values: An Updated View. In Campbell,S. \& Fainstein, S. (eds), Readings in Planning Theory, pp. 265-287,. Cambridge, Mass.: Blackwell Publishers.

Fainstein, S. (2000). New Directions in Planning Theory. Urban Affairs Review, 35 (4), 451-478

Forester, J. (1987). Planning in the Face of Conflict, In LeGates, R.T. \&.Stout, F. (Eds.) (2001) The City Reader, London: Routledge, 410-423.

Forester, J. (1996). Argument, Power, and Passion in Planning Practice. In edited Mandelbaum, S.J., Mazza, L. \& Burchell, L.W. Explorations in Planning Theory (pp. 241-262), New Brunswick, N.J.: Center for Urban Policy Research, Rutgers University

Flyvbjerg, B. (1998). Rationality and Power: Democracy in Practice. Chicago: University of Chicago Press.

Friedmann, J. (1987). Planning in the Public Domain: From Knowledge to Action. Princeton: Princeton University Press.

Friedmann, J. (1992). Empowerment. The Politics of Alternative Development. Cambridge MA \& Oxford UK: Blackwell Publishers.

Healey, P. (1997). Collaborative Planning. Shaping Places in Fragmented Societies. London: Macmillan Press.

Healey, P. Khakee, A., Motte, A. \& Needham, B.(Eds.) (1997). Making strategic spatial plansinnovation in Europe, London: UCL Press.

Healey, P. (2004). Creativity and Urban Governance. Policy Studies, 25 (2), 87 - 102.

Healey, P. (2007) Urban Complexity and Spatial Strategies: Toward a Relational Planning For Our Times. London: Routledge/ RTPI Library Series.

Hoch, C. (1996). A Pragmatic Inquiry about Planning and Power. In Mandelbaum, S.J., Mazza, L. \& Burchell, L.W. (Eds.), Explorations in Planning Theory (pp. 30-44). New Brunswick, N.J.: Center for Urban Policy Research, Rutgers University.

Hoch, C. (2007). Pragmatic communicative action theory. Journal of Planning Education and Research 26 (3), 272-283.

Innes, J. (1995). Planning Theory's Emerging Paradigm: Communicative Action and Interactive Practice. Journal of Planning Education and Research, 14 (3), 183-189.

Innes, J.E., \& Booher, D.E. (1999). Consensus Building as Role Playing and Bricolage: Toward a 
Theory of Collaborative Planning. Journal of the American Planning Association, 65 (1), 9-26 Innes, J.E., \& Booher, D.E. (2004) Reframing Public Participation: Strategies for the 21st Century. Planning, Theory \& Practice, 5 (4), 419 - 436.

Klosterman, R. (1985). Arguments For and Against Planning. Town Planning Review, 56 (1), 5-20

Klosterman, R.E. (1994). Large-Scale Urban Models: Twenty Years Later. Journal of the American Planning Association, 60 (1), 3-6.

Larsen,T.K. (2003). ICT in urban planning. Aalborg University, Jun. From: http://www.akademik. unsri.ac.id/download/journal/files/msgeografi/ICT_in_UrbanPlanning_Torben_Larsen.pdf

Lazarević Bajec, N. (1996). Strateško urbano planiranje, usmeravanje i/ili posredovanje.U: Lazarević Bajec, N. \& Ralević, M. (Eds.) Strategija urbanizacije u uslovima neizvesnosti, str.. 3-28. Beograd: Arhitektonski fakultet.

Lazarević Bajec, N. (2006). Integralni strateški plan opštine. In: V.Trifunović, M. Ralević, (ur) Planiranje, investicije i realizacija u tranziciji ka evropskom zakonodavstvu (str.157 -

167). Beograd: Udruženje urbanista Srbije.

Lazarević Bajec, N. (2007). Tržište i planiranje - debata koja traje. In Janić, M., Trifunović, V., Ralević, M. (ur), Investitori - investicije. Mesto i značaj u izradi strategije prostornog $i$ urbanog razvoja Srbije (str. 35-45). Beograd: Udruženje urbanista Srbije.

Lazarević Bajec,N. (2009). Lokalno strateško planiranje u Srbiji: evaluacija rezultata. Proceedings of the International Conference Regional Development Spatial Planning and Strategic Governance, Vol. 2 (pp.125 - 145). Beograd: Institut za arhitekturu i urbanizam.

Lind, H. (2002). Market-Oriented Land-Use Planning. A conceptual analysis. Planning and Markets, 5, (1). [Electronic version]From: http://www-pam.usc.edu/volume5/v5ila5s1. html\#sec1

Lindblom, C.E. (2001). The Market System. New Haven: Yale University Press.

Lindblom, C.E. (1959). The Science of Muddling Through. Public Administration Review, 19, (2),79-88.

Maruna, M. (2008). Primena metodologija Unified Process-a u urbanističkom planiranju. Unpublished doctoral dissertation. Belgrade: Faculty of Architecture.

Meyerson, M. \& Banfield,E. C. (1955). Politics, Planning and the Public Interest. New York: Free Press.

Mijatović, B. Begović, B., \& Paunović, M. (Novembar 2007) Reforma naknade za uređenje građevinskog zemljišta. Beograd: Centar za liberalno - demokratske studije. From: http://www. clds.org.rs/newsite/Reforma\%20naknade\%20SRPSKI.doc

Mučibabić, D. (2009). Ni presuda iz Strazbura ne ruši divlju kuću. Politika, 28. 11., deo:Beograd.

Pasour, E. (1983). Land-use planning: Implications of the economic calculation debate. Journal of Libertarian Studies, 7 (1), 127-38.

Musil, J. (2005) Why socialist and post-socialist cities are important for forward looking urban studies. Presented at the conference: Forward. Look on Urban Science, Helsinki 26-28 May. From: http://www.valt.helsinki.fi/yhpo/kaupunki/Musil_Why_are_socialist_and_post.doc

Roberson P.J., Choi,T. (2009) Self-organization and Responsiveness: A Simulation of Collaborative Governance. 10th National Public Management Research Conference. Oktobar $1-3$, Columbus Ohio.

Sandercock, L. (1998). Towards cosmopolis: planning for multicultural cities. New York: John Wiley \& Sons.

Savet stranih investitora (2009). Bela knjiga Saveta stranih investitora, predlozi za poboljšanje poslovnog okruženja u Srbiji. Beograd.

Shmueli, D. F., Kaufman, S. \& Ozawa, C. (2008) Mining Negotiation Theory for Planning Insights Journal of Planning Education and Research, 27 (3), 359-364.

Tsenkova, S. (2007). Reinventing Strategic Planning in Post-socialist Cities: Experiences from Sofia, European Planning Studies, 15 (3), 295-317.

Vujović, S. (2004). Akteri urbanih promena u Srbiji. In Milić, A. (ur.) Društvene transformacije 
i strategije društvenih grupa: Svakodnevnica Srbije na početku novog milenijuma. Beograd: Institut za sociološka istraživanja Filozofskog fakulteta

Weber, E. P. \& Khademian, A. M. (2008). Wicked problems, knowledge challenges, and collaborative capacity builders in network settings. Public Administration Review, 68(2), 334349.

Webster, D. (1994). Effective urban management: new challenges, new responses. Regional Development Dialogue, 15, (2). vii-xvi.

World Economic Forum (2009). The Global Competitiveness Report, 2009-2010. Geneva.

* The paper is prepared as a part of the scientific project TP 163013 "Approach and concept for compilation and implementation of Strategy of Spatial Development of Serbia", financed by the Republic of Serbia Ministry of Science and Technological Development. 